\title{
Use of linear programming for decision making: An analysis of cost, time and comfort of rural housing dwellings
}

\author{
Juliano Lovatto ${ }^{1}$, Rodrigo C. Santos ${ }^{2}$, Cristiano M. A. de Souza ${ }^{2}$, Rafael Zucca ${ }^{2}$, Felipo Lovatto ${ }^{3} \&$ \\ Luciano O. Geisenhoff ${ }^{2}$
}

${ }^{1}$ Universidade Federal da Grande Dourados/Prefeitura Universitária, Dourados, MS, Brasil. E-mail: julianolovatto@ufgd.edu.br (Corresponding author) - ORCID: 0000-0002-9876-7546

${ }^{2}$ Universidade Federal da Grande Dourados/Faculdade de Ciências Agrárias, Dourados, MS, Brasil. E-mail: rodrigocouto@ufgd.edu.br - ORCID: 0000- 0003-45859305; csouza@ufgd.edu.br - ORCID: 0000-0002-5347-1709; rafael-zucca@hotmail.com - ORCID:0000-0002-6740-7193; lucianogeisenhoff@ufgd.edu.br - ORCID: 0000-0002-5907-5870

${ }^{3}$ Instituto Federal de Mato Grosso do Sul - Campus Aquidauana, Aquidauna, MS Brasil. Email: felipo.lovatto@ifms.edu.br - ORCID 0000-0002-4059-5497

\begin{abstract}
Brazilian agriculture production requires new types of rural buildings that are more sustainable, economical, and well adapted to their environment. Furthermore, these buildings are no longer simple living quarters, but a way of valuing rural workers. Thus, this study aimed to create a linear programming model for optimizing decision-making when different techniques and construction materials are combined to build rural housing dwellings, thereby enabling an assessment of both the cost and comfort of such buildings. The research considered localizing network facilities via analogies in order to adapt a budget matrix. Three main criteria were applied: cost, runtime, and the environmental comfort provided. The model comprised six construction systems, three types of sealing masonry, two types of roofing, and four types of tiles. Simulations were performed for two Brazilian states, considering the same reference date of validation and comparison. Each input variable resulted in a different construction model. It was demonstrated that the new industrialized construction technologies are advantageous since they provide faster execution, competitive prices, and sustainable raw materials, whilst the application of the criteria to the traditional system of reinforced concrete is also feasible. The linear programming model offers its users an additional decision-making tool for construction systems, enabling time and resource optimization.
\end{abstract}

Key words: budget matrix, optimization, construction techniques

\section{Uso de programação linear para tomada de decisão: Uma análise de custo, tempo e conforto de habitações rurais}

RESUMO: A produção agrícola brasileira demanda novas construções rurais, mais sustentáveis, econômicas e adaptadas ao clima. Além disto, estas construções deixaram de ser simples alojamentos, mas também uma forma de valorização dos trabalhadores rurais. Portanto, o objetivo deste estudo foi a criação de um modelo de programação linear de otimização para auxiliar a tomada de decisão na combinação de diferentes técnicas e materiais construtivos, visando avaliar combinações de custo e conforto para unidades habitacionais rurais. O estudo utilizou a problemática de localização de instalações em redes, para através de analogias adaptar uma matriz orçamentária, aplicando três critérios de escolha, sendo custo, tempo de execução e condições de conforto ambiental proporcionado. O modelo foi composto por seis sistemas construtivos, três tipos de alvenaria de fechamento, dois tipos de estrutura de cobertura e quatro tipos de telhas. Foram realizadas simulações para dois Estados brasileiros, com a mesma data base para validação e comparação. Cada variável de entrada resultou em um modelo construtivo diferente. Verificou-se viabilidade de novas tecnologias construtivas baseadas na industrialização, por possuirem agilidade de execução, preços competitivos e matéria-prima sustentável, e na combinação dos critérios ao sistema tradicional de concreto armado. A programação linear permitiu ao usuário atender suas necessidades sobre tomadas de decisão do sistema construtivo, otimizando tempo e recurso.

Palavras-chave: matriz orçamentária, otimização, técnicas construtivas 


\section{INTRODUCTION}

One of the main challenges faced within engineering and architecture is that of predicting real-estate costs (Marzouk et al., 2018). Many professionals are still empirically deriving the final price and not complying with the expected comfort levels (Magalhães et al., 2018).

The development of computerization and new technologies has increased exponentially within the whole agribusiness chain, including the construction industry (Oliveira, 2018). The increase of agribusiness exports requires new structures, which bring new approaches to rural construction, including technological improvements (Zucca et al., 2018). Supporting the rural population is essential in this process as good-quality housing can improve social welfare and productivity (Çelik et al., 2017).

Rural dwellings are considered simple projects, but when the multitude of variables involved in the construction process are considered, the complexity becomes apparent (Gervásio et al., 2014). Each type of construction presents specific problems which complicate the decision-making process for ascertaining the final costs. Such variables can be managed using optimized algorithms (Machairas et al., 2014).

Multi-objective optimization programs can be used for prompt decision-making since they can solve complex problems (Balali et al., 2014). A network construction of issues, presenting different variables, enables the identification of the best option to meet the user's demands. The benefits of this approach include the reduction in time and costs, alongside improved comprehension of the housing dwelling construction process (Jato-Espino et al., 2014).

Sixty-six percent of rural dwellings are classified as shacks (FJP, 2018). According to Rosemback et al. (2017), the main reason for this classification is the absence of qualified personnel to design, control, and build real-estate. An unqualified workforce, usually hired by the dwellers themselves, produces an uncomfortable dwelling from an ambience point of view, whilst also being small and nondurable due to the poor quality of construction materials used (Pereira \& Freitas, 2017).

Several research publications have described the use of multi-objective linear programming in civil engineering, as demonstrated by Cardoso \& Santos (2017) review paper. However, most articles focus on analyzing construction materials, in order to reduce electricity costs or, simply, optimize the physical and financial planning of dwellings. Therefore, this study aimed to extend this work by developing a budget matrix that combined different inputs in order to determine both the overall level of comfort provided by the dwellings and the construction costs involved. This matrix can be applied as a tool to assist decision-making in the construction process of rural housing dwellings.

\section{Material And Methods}

The network optimized structure was developed using the budget matrix (Figure 1), which comprised the following: six construction systems, three types of sealing, two types of roofing, four types of tiles, and the minimum standard of finishing stated by the Minha Casa, Minha Vida Program Modality Rural - Stage III (MC, 2016).

The architectonic base used to perform this study was the Model of a Basic Project which involves a two-room dwelling with a minimum area of $42 \mathrm{~m}^{2}$, two bedrooms, a kitchen, bathroom, living room and service area (FUNASA, 2017).

The algorithm complied with NBR 15.575 (ABNT, 2013), which states the requirements regarding the durability and comfort of a building. All the project guidelines were also in compliance with the governmental program for financing rural housing dwellings (CAIXA, 2018).

EberickV $10^{\circledast}$ and QiBuilder ${ }^{\circledast}$ software packages were used for determining the dimensions in the structural projects. Ftool 4.0 basic $^{\oplus}$ and Visual Metal v1.5 $5^{\oplus}$ were used to calculate the properties of structural steel. The AutoCad $2018^{\circledR}$ drawing platform was also used in the project.

The combinatorial optimization method was developed considering the localization of the facilities in a network, which is represented by Eq. 1. The suggested network followed the decision-making pathways (Figure 2).

$$
\text { Minimize } F(x)=\sum_{i}^{m} \sum_{j}^{n} C i j X i j+\sum_{j}^{m} F j Y i
$$

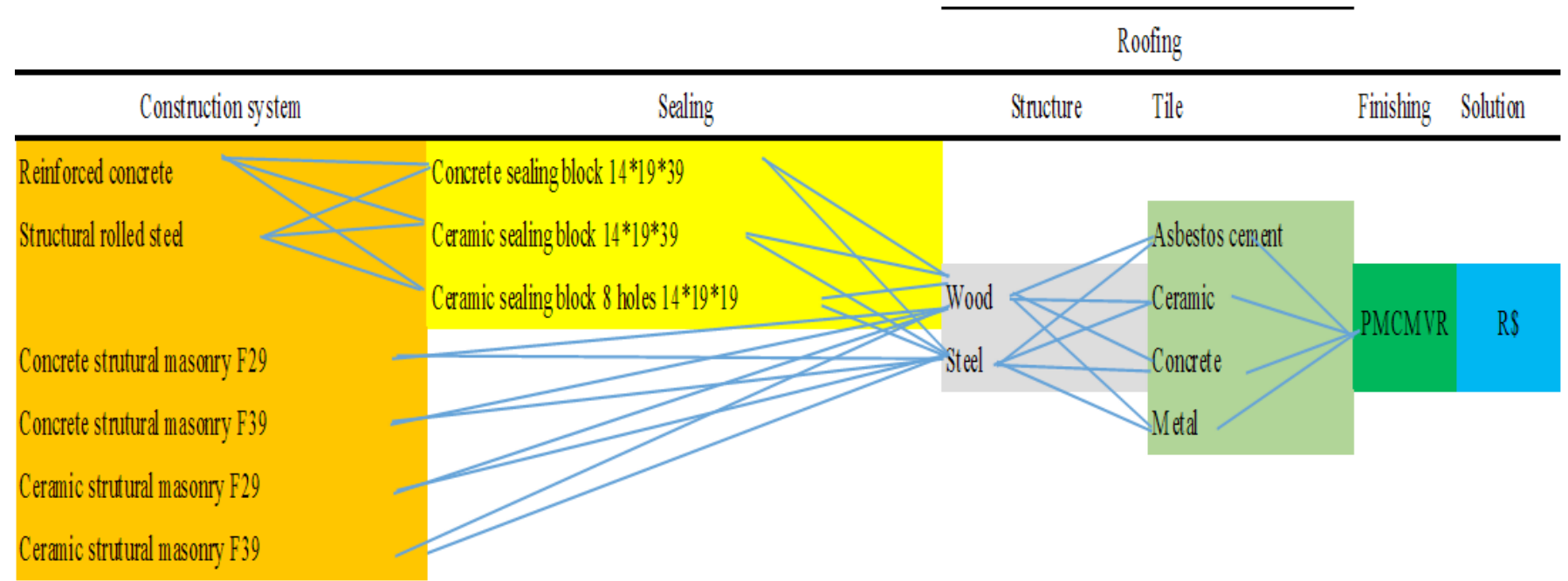

Figure 1. Budget matrix divided by construction steps 


\begin{tabular}{llllll}
\hline Inicial cost Construction system & Sealing & Finishing & Roofing structure & Tile & Dweling \\
\hline
\end{tabular}

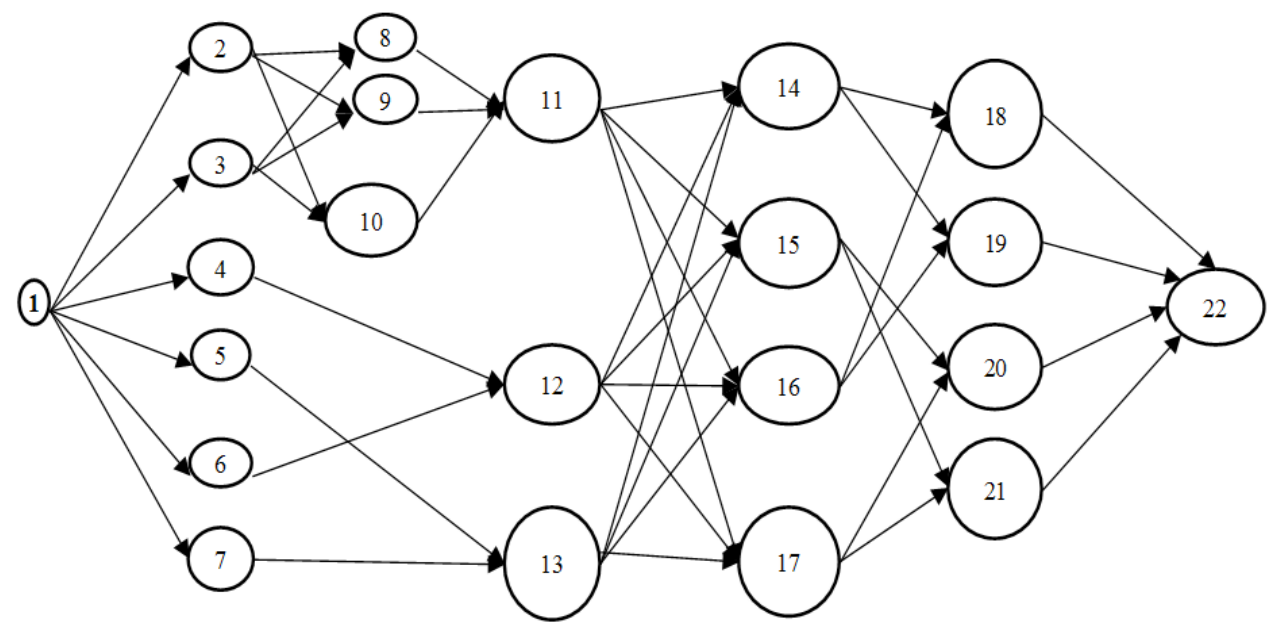

Figure 2. Network structure of the budget matrix, where numbers 1-22 represent the nodes of the optimized structure

Subject to:

$$
\begin{gathered}
\sum_{j}^{m} X i j \geq D j, j=1, \ldots, m \\
\sum_{j}^{n} X i j \leq Q i . Y i, i=1, \ldots, n \\
X i j \geq 0 \forall i, j \\
Y i \in\{0,1\}
\end{gathered}
$$

where:

$\mathrm{F}(\mathrm{x})$ - optimized result;

Cij - period (hours of production) of workforce needed to enter the next stage;

Xij - binary to determine which pathway will be used for each simulation;

Yi - binary to determine which stage will be used for each simulation;

$\mathrm{Fj} \quad$ - construction stage cost determined by the budget matrix;

$\mathrm{Dj}$ - demand for dwellings; and,

Qi - number of dwellings that each node can produce.

The results selected to study each criterion were obtained by modifying Eq. 1 on a case-by-case basis. For the requirement of minimizing the construction time, the element $\sum_{j}^{\mathrm{m}} \mathrm{FjYi}$ was not considered in Eq. 1 and, consequently, the element $\sum_{j}{ }^{n} \mathrm{Xij} \leq \mathrm{Qi} . Y i, \mathrm{i}=1, \ldots, \mathrm{n}$ was excluded from the restrictions. In the lowest cost study, all $\mathrm{X}_{\mathrm{ij}}$ elements were set equal to 1 . Regarding the comfort criterion, only $a_{j}$ values were entered in the equation.

Node ${ }_{1}$ represents the initial cost, including the building site, documentation, and project costs. The construction systems and sealing were organized following the budget matrix (Figure 1), represented by Node to Node $_{7}$ and Node $_{8}$ to Node $_{10}$, respectively.

Since the construction system presented a different internal area, due to modulation of the structural blocks, the finishing costs were also different. Therefore, the costs for each blueprint size are represented from Node $_{11}$ to Node ${ }_{13}$.

The roofing webs depended on the type of tile to be used. Therefore, four different stages were established: wooden webs with ceramic and concrete tiles, wooden webs with asbestos cement and metal tiles, steel webs with ceramic and concrete tiles, steel webs with asbestos cement and metal tiles. These stages are represented by Node to Node $_{17}$. The tiles presenting the same matrix ordinance are denoted by Node ${ }_{18}$ to Node $_{21}$ whilst the number of dwellings is represented by Node $_{22}$.

The thermal comfort penalties suggested and imposed in the model were obtained from simulations conducted at "preojetee.mma.gov.br," which simulates the thermal conditions of the materials chosen in the housing architecture. Indexes $a j$ (Figure 3 ) were applied in the construction system stages of structural masonry, Node ${ }_{4}$ to Node $_{7}$, and the sealing masonry modalities, Node ${ }_{8}$ to Node ${ }_{10}$, to the other structural models. The use of the four roofing models was also considered.

The concrete tile penalty was estimated along with the ceramic tile penalty, since the website did not contain the specific data. However, similar and statistically equal results can be found in the literature (Marafon et al., 2014). The limits allowed in the bioclimatic zone were considered (INMETRO, 2013).

The simulations were performed in two opposite situations. The first simulation was applied to the state of Bahia, Brazil, which has a high rural housing deficit and a basic unit cost per square meter $\left(\mathrm{CUB} \mathrm{m^{-2 }}\right)$ that is among the highest in the country. The state is considered the best place to analyze rural housing dwellings and related public policies. The second simulation involved the state of Mato Grosso do Sul, Brazil, representing the "new" rural population due to the agroindustry. This fact was demonstrated in the study of Medina et al. (2017) regarding the economic situation of Brazilian rural families, emphasizing that welfare-state policies are required in the North and Northeast, in contrast to the Central-West region.

Budget spreadsheets, calculated based on the projects, were used to create Table 1 . The date of reference for both the state 


\begin{tabular}{|c|c|c|c|c|c|c|}
\hline \multicolumn{2}{|c|}{ Construction material } & \multicolumn{2}{|c|}{ Thermal indexes } & \multirow{2}{*}{$\frac{\text { a.j Bahia }}{\text { zone } 6}$} & \multirow{2}{*}{$\frac{a . j M S}{\text { zone } 3}$} & \multirow{2}{*}{$\frac{\text { Stages applied }}{\text { Node }_{8}}$} \\
\hline & Internal mortar $2.5 \mathrm{~cm} /$ Concrete block & Resistance & $0.37 \mathrm{~m}^{2} \mathrm{~K} \mathrm{~W}^{-1}$ & & & \\
\hline & & Transmittance & $2.68 \mathrm{~W} \mathrm{~m}^{-2} \mathrm{~K}^{-1}$ & NMETRO & INMETRO & $\mathrm{Node}_{5}$ \\
\hline & & Thermal delay & $4.5 \mathrm{H}$ & & & $\mathrm{Node}_{4}$ \\
\hline & $14^{*} 19 * 39 \mathrm{~cm} /$ External mortar $2.5 \mathrm{~cm}$ & Thermal capacity & $245 \mathrm{~J} \mathrm{~K}^{-1}$ & 2.68 & 2.68 & \\
\hline & Intemal mortar $2.5 \mathrm{~cm} /$ Ceramic & Resistance & $0.55 \mathrm{~m}^{2} \mathrm{KW}^{-1}$ & zone 6 & zone 3 & Nodeg \\
\hline & block1 $14^{*} 19 * 29 \mathrm{~cm} /$ External mortal 2.5 & Transmittance & $1.83 \mathrm{~W} \mathrm{~m}^{-2} \mathrm{~K}^{-1}$ & NMETRO & INMETRO & $\mathrm{Node}_{10}$ \\
\hline & 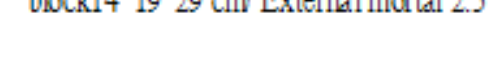 & Thermal delay & $4.2 \mathrm{H}$ & & & $\mathrm{Node}_{6}$ \\
\hline & $\mathrm{cm}$ & Thermal capacity & $161 \mathrm{~J} \mathrm{~K}^{-1}$ & 1.83 & 1.83 & Node $_{7}$ \\
\hline & PVC liner $1 \mathrm{~cm} / \mathrm{Air}$ chamber $(>5,0$ & Resistance & $0.57 \mathrm{~m}^{2} \mathrm{KW}^{-1}$ & zone 6 & zone 3 & $\mathrm{Node}_{19}$ \\
\hline & & Transmittance & $1.75 \mathrm{~W} \mathrm{~m}^{-2} \mathrm{~K}^{-1}$ & NMETRO & INMETRO & $\mathrm{Node}_{20}$ \\
\hline & $\mathrm{cm}) /$ Ceramic roof tile $1,0 \mathrm{~cm}$ & Thermal delay & $1.2 \mathrm{H}$ & & & \\
\hline & & Thermal capacity & $21 \mathrm{~J} \mathrm{~K}^{-1}$ & 1.75 & 1.75 & \\
\hline & PVC liner $1 \mathrm{~cm} /$ Air chamber $(>5,0 \mathrm{~cm})$ & Resistance & $0.568 \mathrm{~m}^{2} \mathrm{~K} \mathrm{~W}^{-1}$ & zone 6 & zone 3 & $\mathrm{Node}_{18}$ \\
\hline & & Transmittance & $1.76 \mathrm{~W} \mathrm{~m}^{-2} \mathrm{~K}-1$ & NMETRO & INMETROA & \\
\hline & Fiber cement tile $0.8 \mathrm{~cm}$ & Thermal delay & $0.4 \mathrm{H}$ & & & \\
\hline & & Thermal capacity & $16 \mathrm{JK}^{-1}$ & 1.76 & 1.76 & \\
\hline & PVC liner $1,0 \mathrm{~cm} /$ Air chamber $(>5,0$ & Resistance & $1.56 \mathrm{~m}^{2} \mathrm{KW}^{-1}$ & zone 6 & zone 3 & $\mathrm{Node}_{21}$ \\
\hline & & Transmittance & $0.6 \mathrm{~W} \mathrm{~m}^{-2} \mathrm{~K}^{-1}$ & NMETRO & INMETRO A & \\
\hline & $\mathrm{cm}) /$ Polys tilane roof tile & Thermal delay & $11.7 \mathrm{H}$ & & & \\
\hline & & Thermal capacity & $13.8 \mathrm{~J} \mathrm{~K}^{-1}$ & 0.6 & 0.6 & \\
\hline
\end{tabular}

Figure 3. Thermal indexes to determine comfort penalties applied to programme. Algorithm input data were collected from unity cost budgets based on the Sistema Nacional de Pesquisa de Custos e Índices da Indústria Civil (SINAPI) - website: orcafascio. com. The programming was run in the educational version of LINDO ${ }^{\circ}$

of Bahia and Mato Grosso do Sul was June 2018. To facilitate a better comprehension of the study, construction stages were organized in groups according to the budget matrix.

Productivity coefficients for the workforce were taken from each arrangement of the services used, and multiplied by the total number of arrangements extracted from the SINAPI compositions used in unit cost budgeting. Thus, the system sections corresponded to the time needed (productive hours) to enter the next stage (Table 2).

\section{Results AND Discussion}

Three different architectonic blueprints were observed when the dwelling structural dimensions were determined (Figure 4), due to the modulation for each family of structural masonry blocks from F29 to F39 (Pereira et al., 2014). The original proposals for the architectural plan were maintained in the blueprints for reinforced concrete and structural steel, confirming that the adaptation to the architectonic project can be simple (Silva et al., 2018). Table 3 shows the modifications presented in the final areas.

The simulation for the state of Bahia, in the city of Irecê (Brazilian bioclimatic zone 6 according to NBR 15.575) resulted in Figure 5 and Table 4. The construction system of structural ceramic blocks F29 with a wooden ceiling and ceramic tiles was determined to be the lowest cost solution.

When two conditions, time and value, are tested simultaneously, the minimum value pathway result can be obtained. Lima et al. (2015) confirmed that structural blocks enable the reduction of runtime when compared with standard masonry. As shown in Riffel et al. (2018), metal tiles have limitations because of their high cost. However, they present higher productivity and thermal comfort. The best project regarding human welfare is a construction system with a combination of structural ceramic masonry F39 and a steel roofing structure with metal sandwich tiles. 
Table 1. Input data to Situation 1: Bahia and Situation 2: Mato Grosso do Sul, for June 2018

\begin{tabular}{|c|c|c|c|c|}
\hline \multirow{2}{*}{ Stage } & \multirow{2}{*}{ Construction solution } & \multirow{2}{*}{ Matrix } & \multicolumn{2}{|c|}{ Price } \\
\hline & & & BA & $\mathrm{MS}$ \\
\hline \multirow{6}{*}{ Construction system } & Reinforced concrete & $\mathrm{Node}_{2}$ & $\mathrm{R} \$ 28,105.32$ & $\mathrm{R} \$ 23,742.02$ \\
\hline & Structural rolled steel & $\mathrm{Node}_{3}$ & $R \$ 29,621.83$ & $\mathrm{R} \$ 25,890.52$ \\
\hline & Concrete structural masonry F29 & $\mathrm{Node}_{4}$ & $\mathrm{R} \$ 31,514.38$ & $\mathrm{R} \$ 32,492.29$ \\
\hline & Concrete structural masonry F39 & $\mathrm{Node}_{5}$ & $\mathrm{R} \$ 37,208.95$ & $\mathrm{R} \$ 37,612.56$ \\
\hline & Ceramic_structural masonry F29 & $\mathrm{Node}_{6}$ & $\mathrm{R} \$ 30,459.00$ & $\mathrm{R} \$ 30,544.66$ \\
\hline & Ceramic structural masonry F39 & $\mathrm{Node}_{7}$ & $\mathrm{R} \$ 36,227.93$ & $\mathrm{R} \$ 35,774.77$ \\
\hline \multirow{3}{*}{ Sealing } & Concrete sealing block $14 \times 19 \times 39 \mathrm{~cm}^{3}$ & $\mathrm{Node}_{8}$ & $\mathrm{R} \$ 5,982.11$ & $\mathrm{R} \$ 6,193.42$ \\
\hline & Ceramic sealing block $14 \times 19 \times 39 \mathrm{~cm}^{3}$ & $\mathrm{Node}_{9}$ & $\mathrm{R} \$ 5,819.73$ & $\mathrm{R} \$ 5,937.11$ \\
\hline & Ceramic sealing block -6 holes $14 \times 9 \times 19 \mathrm{~cm}^{3}$ & $\mathrm{Node}_{10}$ & $\mathrm{R} \$ 11,708.44$ & $\mathrm{R} \$ 10,779.19$ \\
\hline \multirow{3}{*}{ Finishing } & Finishing - Reinforced concrete and steel system & Node $_{11}$ & $\mathrm{R} \$ 41,713.15$ & $\mathrm{R} \$ 39,563.93$ \\
\hline & Finishing - structural masonry system F29 & Node $_{12}$ & $\mathrm{R} \$ 42,012.02$ & $\mathrm{R} \$ 39,993.35$ \\
\hline & Finishing - structural masonry system F39 & $\mathrm{Node}_{13}$ & $\mathrm{R} \$ 39,362.84$ & $\mathrm{R} \$ 39,149.08$ \\
\hline \multirow{4}{*}{ Roofing structure } & Wooden webs for concrete or ceramic tiles & $\mathrm{Node}_{14}$ & $\mathrm{R} \$ 2,233.06$ & $\mathrm{R} \$ 1,557.09$ \\
\hline & Wooden webs for asbestos-cement or metal tiles & Node $_{15}$ & $\mathrm{R} \$ 1,367.24$ & $\mathrm{R} \$ 900.27$ \\
\hline & Steel webs for concrete or ceramic tiles & $\mathrm{Node}_{16}$ & $\mathrm{R} \$ 2,363.97$ & $\mathrm{R} \$ 2,096.79$ \\
\hline & Steel webs for asbestos-cement or metal tiles & Node $_{17}$ & $\mathrm{R} \$ 2,596.69$ & $R \$ 2,261.38$ \\
\hline \multirow{4}{*}{ Tiles } & Asbestos-cement & Node $_{18}$ & $\mathrm{R} \$ 3,287.56$ & $\mathrm{R} \$ 2,791.36$ \\
\hline & Ceramic & $\mathrm{Node}_{19}$ & $\mathrm{R} \$ 1,510.11$ & $\mathrm{R} \$ 2,311.97$ \\
\hline & Concrete & $\mathrm{Node}_{20}$ & $\mathrm{R} \$ 2,402.52$ & $\mathrm{R} \$ 3,099.31$ \\
\hline & Metal and thermoacoustic & $\mathrm{Node}_{21}$ & $\mathrm{R} \$ 14,479.84$ & $\mathrm{R} \$ 8,126.11$ \\
\hline
\end{tabular}

F29 - 29 cm modulation block family; F39 - 39 cm modulation block family

Table 2. Section values in productive hours for both situations of work hours

\begin{tabular}{|c|c|c|c|c|c|c|}
\hline Nodes & & & Sect & ions & & \\
\hline & $X_{12}$ & $X_{13}$ & $X_{14}$ & $X_{15}$ & $X_{16}$ & $X_{17}$ \\
\hline 1 & 692.8569 & 355.019 & 550.4872 & 590.4724 & 564.8787 & 605.1268 \\
\hline & $X_{28}$ & $X_{29}$ & $X_{210}$ & & & \\
\hline 2 & 164.6242 & 143.2939 & 446.61 & & & \\
\hline & $X_{38}$ & $X_{39}$ & $X_{310}$ & & & \\
\hline 3 & 164.8792 & 145.554 & 445.6474 & & & \\
\hline & $X_{412}$ & & & & & \\
\hline 4 & 902.9877 & & & & & \\
\hline & $X_{513}$ & & & & & \\
\hline 5 & 874.3697 & & & & & \\
\hline & $X_{612}$ & & & & & \\
\hline 6 & 902.9877 & & & & & \\
\hline & $X_{713}$ & & & & & \\
\hline 7 & 874.3697 & & & & & \\
\hline & $X_{813}$ & & & & & \\
\hline 8 & 942.9384 & & & & & \\
\hline & $X_{911}$ & & & & & \\
\hline 9 & 942.9384 & & & & & \\
\hline & $X_{1011}$ & & & & & \\
\hline 10 & 942.9384 & & & & & \\
\hline & $X_{1114}$ & $X_{1115}$ & $X_{1116}$ & $X_{1117}$ & & \\
\hline 11 & 37.12522 & 13.6493 & 16.53804 & 22.96548 & & \\
\hline & $X_{1214}$ & $X_{1215}$ & $X_{1216}$ & $X_{1217}$ & & \\
\hline 12 & 37.92898 & 14.02853 & 17.49483 & 23.60355 & & \\
\hline & $X_{1314}$ & $X_{1315}$ & $X_{1316}$ & $X_{1317}$ & & \\
\hline 13 & 39.11874 & 14.4687 & 17.53071 & 24.34395 & & \\
\hline & $X_{1418}$ & $X_{1419}$ & & & & \\
\hline 14 & 29.85932 & 21.97433 & & & & \\
\hline & $X_{1520}$ & $X_{1521}$ & & & & \\
\hline 15 & 23.16583 & 11.47165 & & & & \\
\hline & $X_{1618}$ & $X_{1619}$ & & & & \\
\hline 16 & 29.85932 & 21.97433 & & & & \\
\hline & $X_{1720}$ & $X_{1721}$ & & & & \\
\hline 17 & 23.16583 & 11.47165 & & & & \\
\hline
\end{tabular}

If the best alternative, comprising all the variables, was chosen, the dwelling would present a load-bearing structure of reinforced concrete, masonry of ceramic blocks sized $14^{\star} 19^{\star} 39 \mathrm{~cm}^{3}$, and wooden webs with metal and thermoacoustic tiles. Therefore, the different construction alternatives were presented in combinations, which enables

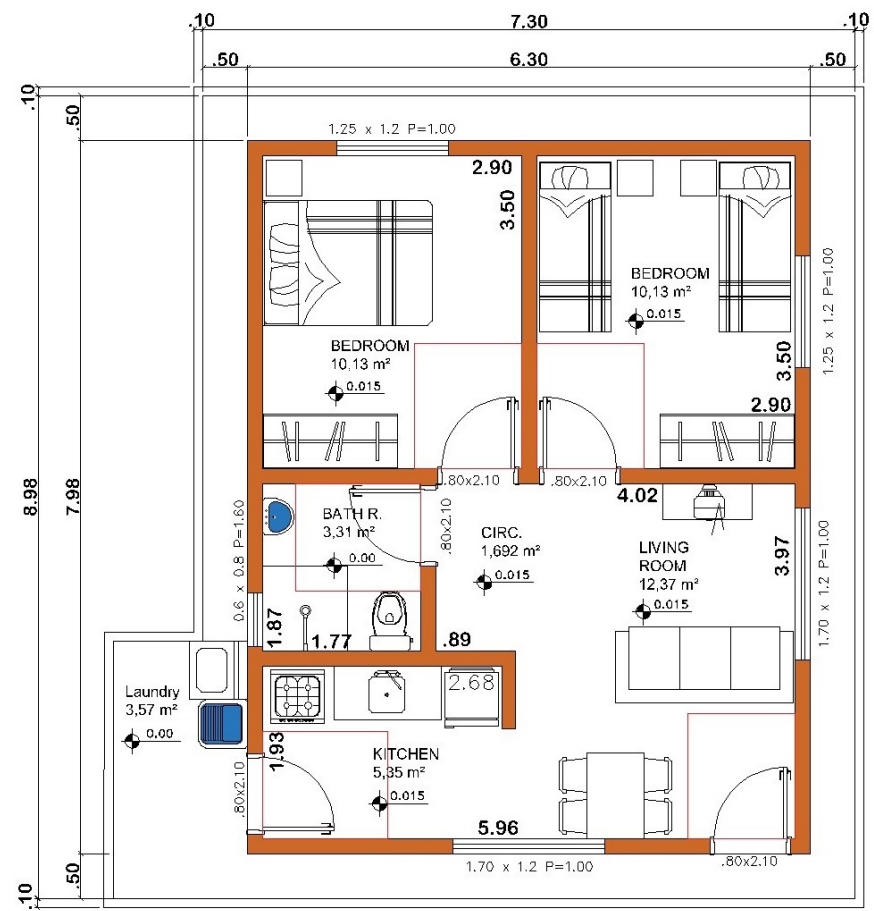

ARCHITECTURAL FLOOR PLAN

Figure 4. Architectural floor plan for the calculation of the reinforced concrete and structural rolled steel construction systems

Table 3. Architectonic blueprint areas

\begin{tabular}{lcccc}
\hline \multirow{2}{*}{ Blueprints } & Total area & Net area & Roofing area & \begin{tabular}{c} 
Index \\
\cline { 2 - 4 } of utilization (\%)
\end{tabular} \\
\cline { 2 - 4 } CA and Steel & 50.27 & 43.48 & 72.22 & 86.49 \\
AE F29 & 52.24 & 46.48 & 74.22 & 88.97 \\
AE F39 & 54.21 & 48.37 & 76.55 & 89.24 \\
\hline
\end{tabular}

CA - Reinforced concrete; AE - Structural masonry; F29 $29 \mathrm{~cm}$ modulation block family; F39 $39 \mathrm{~cm}$ Modulation block family

the most beneficial option to be offered to clients (Delgarm et al., 2016).

In order to apply the thermal penalty coefficients (Table $1)$, cities located in the countryside where agribusiness 


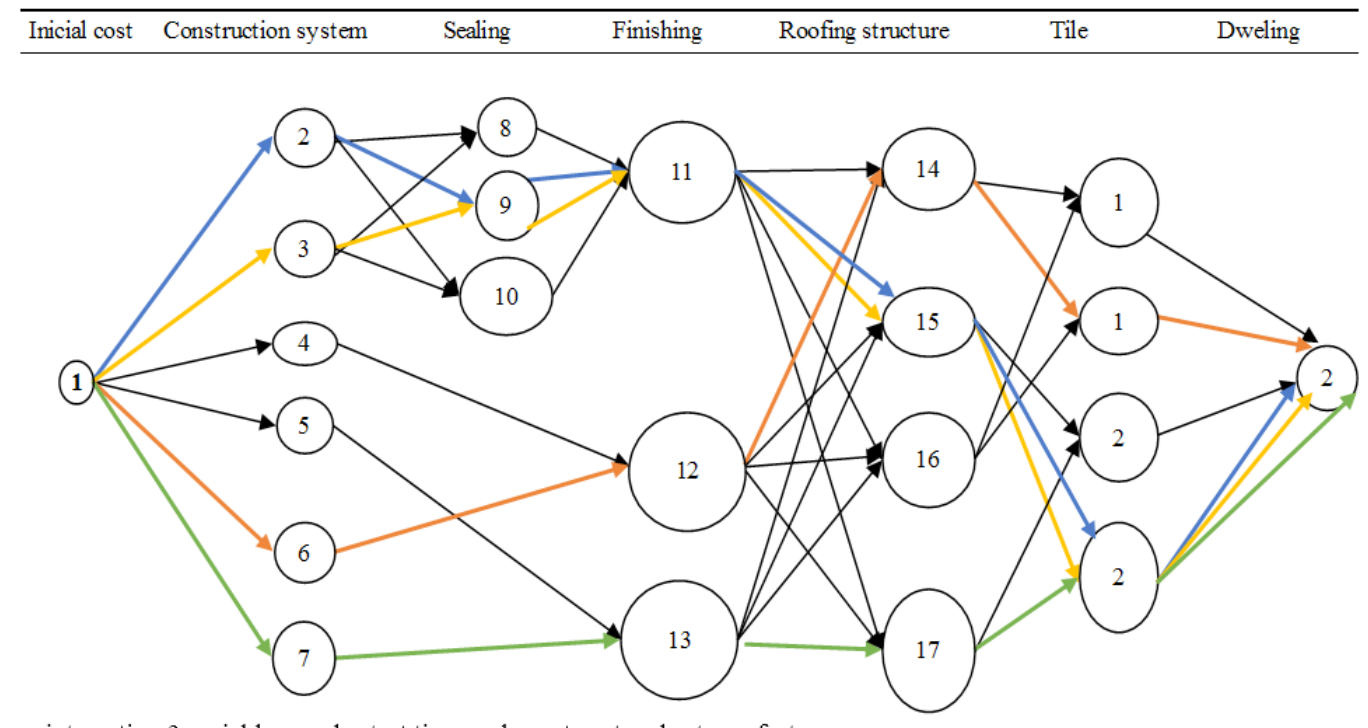

-- interaction 3 variables; - shortest time; -- lowest cost; -- best comfort

Figure 5. Best solution of rural houses for Irecê, Bahia state, June 2018

Table 4. Results of the simulation for Bahia state, June 2018

\begin{tabular}{|c|c|c|c|c|c|c|}
\hline \multirow{2}{*}{ Situation } & \multicolumn{4}{|c|}{ Pathways } & \multicolumn{2}{|c|}{ Result } \\
\hline & Structural system & Masonry & Roofing & Tille & Value (R\$) & Time (h) \\
\hline Lowest cost & Ceramic block F29 & - & Wood & Ceramic & $76,219.19$ & $1,527.77$ \\
\hline Shortest time & Structural rolled steel & $\begin{array}{l}\text { Sealing ceramic } \\
\text { block }\end{array}$ & Wood & $\begin{array}{l}\text { Metal and } \\
\text { thermoacoustic }\end{array}$ & $93,001.79$ & $1,468.63$ \\
\hline Best comfort & Ceramic block F39 & - & Steel & $\begin{array}{l}\text { Metal and } \\
\text { thermoacoustic }\end{array}$ & $92,667.30$ & $1,515.57$ \\
\hline $\begin{array}{l}\text { Cost }+ \text { time }+ \\
\text { comfort }\end{array}$ & Reinforced concrete & $\begin{array}{l}\text { Sealing ceramic } \\
\text { block }\end{array}$ & Wood & $\begin{array}{l}\text { Metal and } \\
\text { thermoacoustic }\end{array}$ & $79,381.40$ & $1,804.21$ \\
\hline
\end{tabular}

is conducted, Irecê and Dourados, were chosen. The study conducted by Dacanal et al. (2018) emphasized that construction techniques intended to reduce cooling generated by energy need to be used in agricultural buildings. Furthermore, the word of Oliveira et al. (2018) demonstrated the energy crisis in the Brazil, emphasizing the importance of studying construction ambience techniques.

The simulation conducted for Dourados, MS, Brazil, resulted in Figure 6 and Table 5. The housing unit presenting the lowest cost was also subjected to three different criteria: reinforced concrete structure, ceramic blocks sized $14 \times 19 \times 39 \mathrm{~cm}^{3}$ used as masonry sealing, and wood with ceramic tile webs. There was no change regarding the variables of time and comfort from those of the previous simulation.

The network demonstrates that the location of the experimental construction region influences the simulation results. When the variables are isolated, the use of metal and thermoacoustsic tiles is most convenient. Sealing masonry, structural or concrete sealing, did not present economic benefits through the network, due to the raw material costs.

Another difference is related to ceramic and concrete transmittance weight; notwithstanding the application of

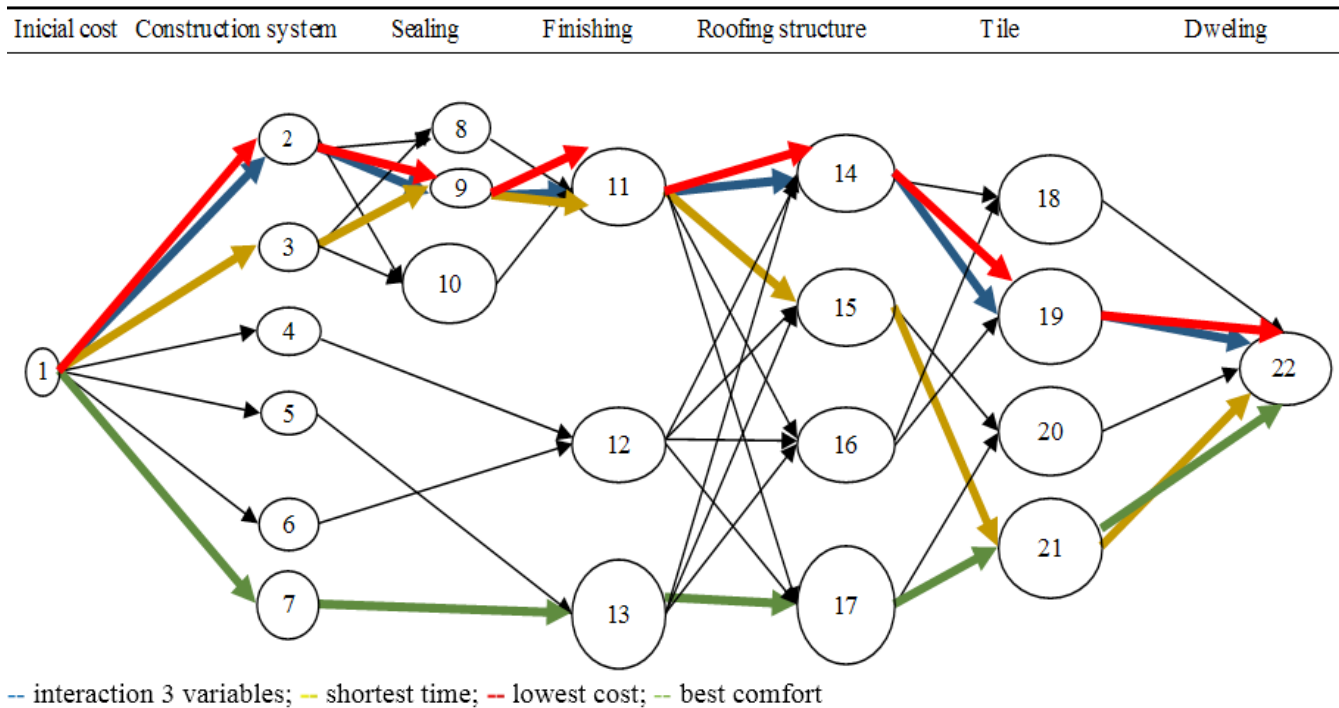

-- interaction 3 variables; - shortest time; -- lowest cost; -- best comfort

Figure 6. Best solution of rural houses for Dourados, Mato Grosso do Sul state, Brazil, June 2018 
Table 5. Results of the simulation for Mato Grosso do Sul state, Brazil, June 2018

\begin{tabular}{|c|c|c|c|c|c|c|}
\hline \multirow{2}{*}{ Situation } & \multicolumn{4}{|c|}{ Pathway } & \multicolumn{2}{|c|}{ Result } \\
\hline & Structural system & Masonry & Roofing & Tille & Value (R\$) & Time (h) \\
\hline Lowest cost & Reinforced concrete & Ceramic sealing block & Wood & Ceramic & $73,118.72$ & $1,838.19$ \\
\hline Shortest time & Structural rolled steel & Ceramic sealing block & Wood & $\begin{array}{l}\text { Metal and } \\
\text { thermoacoustic }\end{array}$ & $80,417.94$ & $1,468.63$ \\
\hline Best comfort & Ceramic block F39 & - & Steel & $\begin{array}{l}\text { Metal and } \\
\text { thermoacoustic }\end{array}$ & $85,311.34$ & $1,515.57$ \\
\hline $\begin{array}{l}\text { Cost }+ \text { time }+ \\
\text { comfort }\end{array}$ & Reinforced concrete & Ceramic sealing block & Wood & Ceramic & $73,118.72$ & $1,838.19$ \\
\hline
\end{tabular}

the aj penalty, studies comparing the two masonries have indicated that both are statistically equal. Qualitatively, they have indicated that using concrete blocks is better than using ceramic blocks in ground buildings (Sacht \& Rossignolo, 2009; Santos et al., 2015).

The Technical Regulation for Quality of Energy Efficiency in Commercial Buildings of Public Services (RTQ-C) (INMETRO, 2013) was used to assess climate considerations by region, showing that all construction methods, masonries and roofing types achieve an "A" level of efficiency. The bioclimatic architecture shows the importance of using construction materials and techniques in an appropriate way, in order to mitigate the climatic influence over the building, providing the eight Brazilian bioclimatic zones with improved construction solutions for human comfort in architectonic projects (Guarda et al., 2018).

Although more expensive, the sandwich tile is the best method for ensuring the thermal comfort of a dwelling. On the contrary, ceramic and asbestos cement tiles were economically more advantageous and, therefore, presented a better priceperformance ratio.

In both cases, if all the restrictions are considered, the standard construction system is the most feasible. Nevertheless, when compared to the other industrialized techniques studied, this system is less environmentally sustainable, since it produces more waste. Thus, the standard construction system is not considered the most attractive alternative within industry 4.0 (Barbosa et al., 2017).

The industrialization of construction techniques, presenting modulation characteristics, provides a faster runtime and a more sustainable construction process for housing dwellings, as stated by Pereira et al. (2014). When new technical solutions are included in the programming, new pathways can emerge through feedback, improving the combinatorial model proposed (Penna et al., 2015).

The model presents almost exact budget values concerning the masonry and roofing areas. The highest difference in the measures between two projects was observed between steel to masonry, and structural masonry F39 to roofing. Notwithstanding considerations regarding technical feasibility, the error rate is below the recommended unit costs budget, estimated to within 10\% (Fernandes et al., 2017).

\section{Conclusions}

1. The combinatorial result using multicriteria demonstrated that, when considering time of construction, choosing industrialized building technologies, such as rolled steel and structural masonry, is possible.
2. The greatest level of thermal comfort for a dwelling requires the use of sandwich metal tiles, although they may be the more expensive alternative.

3. The linear programming approach allows the optimization of time and resources, enabling high productivity, reduced costs and high quality in the construction process.

4. The combination of the three restrictions would be the most suitable for each state, as it optimizes what is expected from a construction in terms of cost, time, and quality. In other words, traditional techniques must be used with industrialized materials. For both states, this involves reinforced concrete structures with ceramic F39 sealing blocks, a wooden structure roof and ceramic tiles for MS and thermoacoustic metal for BA.

\section{Literature Cited}

ABNT - Associação Brasileira de Normas Técnicas. NBR 15575-1: Edificações habitacionais - Desempenho - Parte 1: Requisitos gerais. 2.ed. Rio de Janeiro: ABNT, 2013.52p.

Balali, V.; Zahraie, B.; Roozbahani, A. Integration of ELECTRE III and PROMETHEE II decision-making methods with an interval approach: Application in selection of appropriate structural systems. Journal of Computing in Civil Engineering, v.28, p.297314, 2014. https://doi.org/10.1061/(ASCE)CP.1943-5487.0000254

Barbosa, M. T.; Cruz, A. F.; Castanõn, J. A. Análise do processo de manutenção em diferentes sistemas construtivos no Brasil. Revista de Engenharia da Universidade Católica de Petrópolis, v.11, p.33-43, 2017.

CAIXA - Caixa Econômica Federal. Minha Casa Minha Vida Habitação rural: A grande chance de o trabalhador rural morar no que é seu. 3.ed. Brasília: CAIXA, 2018. 3p.

Çelik, T.; kamali, S.; Arayici, Y. Social cost in constrution projects. Environmental Impact Assessment Review, v.26, p.77-86, 2017. https://doi.org/10.1016/j.eiar.2017.03.001

Cardoso, T. A.; Santos, A. P. L. Métodos multicritério de apoio à decisão no planejamento de construções e reformas de edificações. Revista Espacios, v.38, p.12-30, 2017.

Dacanal, C.; Luz, S. N.; Turco, S. H. N.; Vasconcelos, O. C. M. Diagnosis and recommendations for the bioclimatic desing of grape packing house in hot and dry climate. Engenharia Agrícola, v.38, p.1-6, 2018. https://doi.org/10.1590/1809-4430-eng.agric. v38n1p1-6/2018

Delgarm, N.; Sajadi, B.; Kowsary, F.; Delgarm, S. Multi-objective optimization of the building energy performance: A simulationbased approach by means of particle swarm optimization (PSO). Applied Energy, v.170, p.293-303, 2016. https://doi. org/10.1016/j.apenergy.2016.02.141 
Fernandes, P. M.; Castro, M.; Godinho, C.; Perez, S. T. C. Um estudo comparativo entre o orçamento por composição de custo unitário e o orçamento por estimativa utilizando o índice da SINDUSCON CUB/M². Revista Pensar Engenharia, v.5, p.1-9, 2017.

FJP - Fundação João Pinheiro. Déficit habitacional no Brasil. Estatísca e infomações: Demografia e indicadores sociais: déficit habitacional no Brasil -2018. 1.ed. Brasília: FJP, 2018.78p.

FUNASA - Fundação Nacional da Saúde. Modelo de projeto básico de habitação de 2 quartos planta baixa. 1.ed. Brasília: FUNASA, 2017. 1p.

Gervásio, H.; Santos, P.; Martins, R.; Silva, L. S. da. A macrocomponent approach for the assessment of building sustainability in early stages of design. Building and Environment, v.73, p.256270, 2014. https://doi.org/10.1016/j.buildenv.2013.12.015

Guarda, E. L. A. da; Durante, L. C.; Callejas, I. J. A.; Jorge, S. H. M.; Brandão, R. P. Estratégias construtivas para adequação da envoltória de uma habitação de interesse social às zonas bioclimáticas mato-grossenses. E \& S Engineering and Science, v.7, p.45-57, 2018. https://doi.org/10.18607/ES201876138

INMETRO - Instituto Nacional de Metrologia, Qualidade e Tecnologia. Regulamento técnico da qualidade para nível de eficiência energética da edificações comerciais, de serviços e públicas - RTQ-C. 1.ed. Brasília: INMETRO, 2013. 93p.

Jato-Espino, D.; Lopez, E. C.; Hernandez, J. R.; Jordana, J. C. C. A review of application of multi-criteria decision making methods in construction. Automation in Construction, v.45, p.151-162, 2014. https://doi.org/10.1016/j.autcon.2014.05.013

Lima, F. E. C.; Carneiro, L. B.; Oliveira, J. J. Índice de produtividade na execução de alvenaria: Estudo de caso na edificação de um laboratório para UFERSA-CARAUBAS-RN. Vetor - Revista de Ciências Exatas e Engenharias, v.25, p.76-94, 2015.

Machairas, V.; Tsangrassoulis, A.; Axarli, K. Algorithms for optimization of building design: A review. Renewable and Sustainable Energy Reviews, v.31, p.101-112, 2014. https://doi. org/10.1016/j.rser.2013.11.036

Magalhães, R. M.; Mello, L. C. B. B.; Bandeira, R. A. M. Planning and control of civil works: Multiple case study in Rio de Janeiro construction companies. Gestão \& Produção, v.25, p.44-55, 2018. https://doi.org/10.1590/0104-530x2079-15

Marafon, C.; Laco, M.; Sanches, J. C. M.; Leão, M.; Leão, E. F. T. B. Estratégias bioclimáticas em avaliação de desempenho térmico nas habitações de interesse social em Sinop/MT. Revista Eletrônica em Gestão, Educação e Tecnologia Ambiental, v.18, p.1008-1021, 2014. https://doi.org/10.5902/2236117013815

Marzouk, M.; Azab, S.; Metawie, M. BIM-based approach for optimizing life cycle costs of sustainable buildings. Journal of Cleaner Production, v.188, p.217-226, 2018. https://doi. org/10.1016/j.jclepro.2018.03.280

MC - Ministério das Cidades. Anexo II - Especificações mínimas das unidades habitacionais. 3.ed. Brasília: MC, 2016. 6p.
Medina, G.; Novaes, E.; Teixeira, S. M. Desenvolvimento local em territórios empobrecidos: Possibilidades de inclusão social e produtiva de produtores rurais. Interações, v.18, p.5-18, 2017. https://doi.org/10.20435/1984-042X-2017-v.18-n.1(03)

Oliveira, D. da C.; Souza, R. E. de; Silva, G. G. da. Análise da implantação de um sistema de energia solar fotovoltaica em uma residência da zona rural. Revista Pensar Acadêmico, v.16, p.40-48, 2018. https://doi.org/10.21576/rpa.2018v16i1.324

Oliveira, N. M. de. Produção agropecuária agregada: Uma aplicação para o estado do Tocantins. Desafios, v.5, p.135-147, 2018. https:// doi.org/10.20873/uft.2359-3652.2018vol5n1p135

Penna, P.; Prada, A.; Cappelletti, F.; Gasparella, A. Multi-objectives optimization of energy efficiency measures in existing buildings. Energy and Buildings, v.95, p.57-69, 2015. https://doi. org/10.1016/j.enbuild.2014.11.003

Pereira, A. C.; Freitas, J. C. de. Ocupações irregulares em São Paulo. Revista de Pós-Graduação Multidisciplinar, v.1, p.113-120, 2017.

Pereira, T. da S.; Alves, F. C.; Gomes, L. G.; Silva, M. H.; Rosa, S. R.; Silva, S. L.; Pinto, C. O. Estudo comparativo entre alvenaria estrutural e alvenaria de vedação comum. Blucher Engineering Proceedings, v.1, p.25-26, 2014. https://doi.org/10.5151/biochem-8entec-012

Riffel, C. F.; Zardo, C. R.; Camargo, A.; Barbisan, A. O. Estudo de viabilidade técnica e custos para execução de coberturas com telhas metálicas termoisolantes, fibrocimento e policarbonato. Anais da Engenharia Civil, v.1, p.157-174, 2018.

Rosemback, R. G.; Rigotti, J. I. R.; Feitosa, F. F.; Monteiro, A. M. V. Demografia, planejamento territorial e a questão habitacional: Prognóstico da situação habitacional do Litoral Norte Paulista. Revista Brasileira de Estudos de População, v.34, p.301-320, 2017. https://doi.org/10.20947/S0102-3098a0005

Sacht, H. M.; Rossignolo, J. A. Habitações térreas e multipavimentos de interesse social: Avaliação de desempenho térmico para tipologias com vedação em alvenaria de blocos cerâmicos e de concreto. Pesquisa em Arquitetura e Construção, v.1, p.1-18, 2009. https:// doi.org/10.20396/parc.v1i4.8634498

Santos, J. C. P. dos; Kothe, K. K.; Mohamad, G.; Vaghetti, M. A. O; Rizzati, E. Comportamento térmico de fechamentos em alvenaria estrutural para a Zona Bioclimática 2 brasileira. Revista Matéria, v.20, p.1030-1047, 2015. https://doi.org/10.1590/S1517707620150004.0106

Silva, D. B. M.; Sales, F. M.; Silva, L. A.; Silva, M. S. Análise comparativa entre alvenaria estrutural e concreto armado. REMAS-Revista Educação, Meio Ambiente e Saúde, v. 7, p. 103-118, 2018.

Zucca, R.; Vieira Neto, J. G.; Santos, R. C.; Lovatto, J.; Costa, M. V. da. Uso de resíduos de construção como agregado graúdo destinado à confecção de blocos para alvenaria de vedação. Enciclopédia Biosfera, v.15, p.1381-1392, 2018. https://doi.org/10.18677/ EnciBio_2018A119 